\section{Variability in the Relationship between Frost Temperature and Injury Level for Some Cultivated Prunus Species}

\author{
Carlos Miranda, Luis G. Santesteban, and José B. Royo \\ Departamento de Producción Agraria, Sección de Fruticultura y Viticultura, \\ Universidad Pública de Navarra, Campus de Arrosadía, 31006 Pamplona, Spain
}

Additional index words. spring frost, critical temperatures, bud sensibility, Prunus persica, Prunus dulcis, Prunus salicina, Prunus spinosa, Prunus avium

\begin{abstract}
The influence of the species in spring frost sensibility was determined for the Prunus species peach (P. persica (L.) Batsch), sweet cherry (P. avium L.), almond (P. dulcis (Mill.) Webb/P. amygdalus Batsch), japanese plum (P. salicina Lindl.), and blackthorn (P. spinosa L.). The confidence intervals for lethal temperatures of $10 \%\left(\mathrm{LT}_{10}\right)$ and $90 \%\left(\mathrm{LT}_{90}\right)$ bud injury were also determined. In 2000 and 2001, seven frost treatments were made for each one of the phenological stages comprised between B (first swell) and I (jacket split) in two cultivars per each species. The relationships between frost temperature and the proportion of frost damaged buds for each cultivar, year, and phenological stage were adjusted to linear regression models. The $\mathbf{9 5 \%}$ confidence intervals were also calculated. The spring frost hardiness order of the species, from the least to most hardy, was as follows: sweet cherry, almond, peach, japanese plum, and blackthorn. Despite the highly homogeneous nature of the frost and bud characteristics, the temperature range for a given injury degree was quite broad, since the confidence interval's breadth for $\mathrm{LT}_{10}$ was as high as about $3{ }^{\circ} \mathrm{C}$ and as high as about $6^{\circ} \mathrm{C}$ for $\mathrm{LT}_{90^{\circ}}$. Consequently, when critical temperatures are used in making decisions as to when to begin active frost protection, a prudent measure would be to take the temperature references from the upper limits in the confidence intervals.
\end{abstract}

Spring frost injury limits the productivity of fruit trees, in particular stone fruit, so it becomes an important environmental constraint. Thus, providing additional protection to avoid frost becomes needed. The essential condition for effective frost protection depends on the time in which protection systems are connected, so it is necessary to know the critical temperatures for each species. Air temperature indices have been developed through research and field experience and are used to inform producers of the temperature at which serious freeze damage would occur in floral structures. Information about these temperatures may be used in making decisions about when to begin operating active protection systems and when they may be safely turned off. To determine flower bud hardiness, the temperatures at which injury to the buds occurs are $10 \%$ and $90 \%$ (designated $\mathrm{LT}_{10}$ and $\mathrm{LT}_{90}$ ); these indices are commonly used to determine, respectively, the temperature at which injury occurs and at which few buds survive (Faust, 1989). Critical temperatures, defined as the temperatures that buds can withstand for half an hour, are also commonly used (Ossaer et al., 1998; Saunier, 1960).

The temperature at which fruit buds are injured depends primarily on their stage of development. Buds are most hardy during the winter when they are fully dormant. As they begin to swell and expand into blossoms, they become

Received for publication 30 June 2004. Accepted for publication 11 Sept. 2004. This study was financed by Agroseguro S.A.,Agrupación Española de Entidades Aseguradoras de los Seguros Agrarios Combinados S.A. C/Gobelas 23, 28023 Madrid, España

${ }^{1}$ To whom reprint request should be addressed; e-mail carlos.miranda@unavarra.es. less resistant to freeze injury. Not all blossom buds are equally tender. Resistance to freeze injury varies within trees as it does among species orchards, cultivars, (Proebsting and Mills, 1978; Saunier, 1960), and even within the tree itself (Westwood, 1993). Resistance to freeze among buds of different cultivars of the same species may be even higher than among different species (Pfammatter and Evequoz, 1975). Buds that develop slowly tend to be more resistant (Osaer et al., 1998), and their sugar or starch contents influence freezing tolerance (Ercisli, 2003). Cultural practices, orchard topography, rates of temperature decrease, and the duration of low temperatures also influences the extent of cold injury (Rodrigo, 2000). As a result, some buds usually are killed at higher temperatures, while others are resistant at much lower temperatures. Therefore, it is difficult to make an accurate determination of the standard critical temperatures for bud injury. However, it could be feasible to determine with greater accuracy the temperature interval at which a certain degree of injury could be expected.

At the moment, several critical temperature indices for peach (P.persica (L.) Batsch), sweet and sour cherry (P. avium L. and P. cerasus L.), european plum ( $P$. domestica L.), and apricot (P. armeniaca L.) are available in the literature (Ballard etal., 1987, 1994, 1997 and 1999; Osaer et al., 1998; Proebsting y Mills, 1978; Perraudin, 1965, Saunier, 1978). For other Prunus species such as almond (P.dulcis (Mill.) Webb/P. amygdalus Batsch) and Japanese plum ( $P$. salicina Lindl.), critical temperature indices have been obtained only for the stages first pink, full bloom, and jacket split (Grasselly, 1982; Micke, 1996; Saunier, 1960). For blackthorn (P. spinosa L.), a species of local interest, no indices have been developed yet. Those critical temperatures have usually been obtained from field observations after natural spring frosts; so it is very difficult to compare the information on critical temperatures available in the literature and deduce the influence of the species over bud frost hardiness because of the lack of a standardized methodology. The work of Proebsting and Mills (1978) is the only reference known by the authors in which $\mathrm{LT}_{10}$ and $\mathrm{LT}_{90}$ for some Prunus species have been obtained through laboratory testunder controlled conditions. However, those indices were developed for cultivars which, at least in Europe, are considered to have been superseded and have not been planted for years.

The objectives of this study were 1) to determine, using a common methodology, the influence of the specie in the spring frost bud sensibility for some of the most cultivated Prunus species, and 2) to determine, for the same species, the confidence intervals for the lethal temperatures for $10 \%\left(\mathrm{LT}_{10}\right)$ and $90 \%$ $\left(\mathrm{LT}_{90}\right)$ bud injury.

\section{Materials and methods}

Data collection. The study was conducted in the years 2000 and 2001 in fully producing commercial orchards (Table 1) of the Prunus species peach, almond, sweet cherry, Japanese plum and blackthorn, ranging between 7 and 12 years. The orchards had normal yields from at least the two years prior to the beginning of the study to the end of it. The cultivars were some of the most cultivated, and none of them was reputed to be particularly frost tender or hardy, except for Ferragnès and Marcona almonds, which are considered quite frost tender.

Frost treatments were made for all the phenological stages from B (first swell) to I(jacket split)(Baggiolini, 1952; Felipe, 1977). Stage E, in which the stamens are already visible and the flowers are ready to open, lasted only for a few hours both years, so no samples were taken for it. Ten trees per cultivar were assessed daily for developing bloom on each species; when about $50 \%$ of the buds on the trees had reached the desired phenological stage, a number of spurs (1year-old shoots in the case of peach) belonging to the desired stage were placed in an insulated container and then were carried quickly to the laboratory. Spurs (or shoots) were taken so that they represented all the positions on the trees and in the ratio at which they occurred. Seven frost treatments were made for each cultivar and phenological stage. For each frost treatment, spurs and shoots with about 250 buds total from the desired stage were spread (with care being taken to dissipate easily latent heat by avoiding large tissue masses) into a chamber (432 L; ASLAparatos Científicos, Madrid, Spain). This programmable chamber is equipped with a heatcold unit working in the $-20^{\circ} \mathrm{C}$ to $30^{\circ} \mathrm{C}$ range, $-0.3^{\circ} \mathrm{C}$ precision. Five thermopar probes connected to a datalogger (LI-100; LI-COR, Inc., Lincoln, Neb.) were placed near the samples. Air temperature in the chamber was maintained at 7 ${ }^{\circ} \mathrm{C}$ for $45 \mathrm{~min}$ and then programmed to decline by $2{ }^{\circ} \mathrm{C} \cdot \mathrm{h}^{-1}$ until the desired frost temperature (FT) was reached. The FT was maintained for 
Table 1. Species and cultivars and rootstocks employed in the study.

\begin{tabular}{lll}
\hline Species & Cultivars used in the study & Rootstock \\
\hline Almond [Prunus dulcis (Mill.) Webb/P. amygdalus Batsch] & Marcona, Ferragnès & GF-305 \\
Peach [Prunus persica (L.) Batsch] & Baby Gold 6, Queen Giant & GF-677 \\
Japanese plum (Prunus salicina Lindl.) & Black Gold, Larry Anne, Fortune, Royal Diamond, Songold & Mariana GF 8-1 \\
Sweet cherry (Prunus avium L.) & Burlat, Sunburst & SL-64 \\
Blackthorn (Prunus spinosa L.) & CRPN 1, CRPN 4, CRPN 6 & Brompton \\
\hline${ }^{2}$ Clonal selections from Consejo Regulador de la Denominación de Origen 'Pacharan de Navarra' and Instituto Técnico de Gestión Agricola of Navarra.
\end{tabular}

Table 2. Range of frost temperatures (FT) essayed for each phenological stage (PE) and specie in the study. Seven frost temperatures, evenly distributed, were programmed within the maximum (MAX) and minimum (MIN) temperature range, both included. The starting temperature was always $7^{\circ} \mathrm{C}$, and declined by $2{ }^{\circ} \mathrm{C} \cdot \mathrm{h}^{-1}$ until FT was reached. FT was maintained for $30 \mathrm{~min}$ and then increased up to $7^{\circ} \mathrm{C}$ by $3{ }^{\circ} \mathrm{C} \cdot \mathrm{h}^{-1}$.

\begin{tabular}{|c|c|c|c|c|c|c|c|c|c|c|}
\hline \multirow[b]{2}{*}{$\mathrm{PE}^{\mathrm{z}}$} & \multicolumn{2}{|c|}{ Peach } & \multicolumn{2}{|c|}{ Almond } & \multicolumn{2}{|c|}{ Japanese plum } & \multicolumn{2}{|c|}{ Blackthorn } & \multicolumn{2}{|c|}{ Sweet cherry } \\
\hline & $\begin{array}{l}\text { MAX } \\
\end{array}$ & MIN & MAX & MIN & MAX & MIN & MAX & MIN & MAX & MIN \\
\hline $\mathrm{C}$ & -7.3 & -12.4 & -3.1 & -12.9 & -3.2 & -17.1 & -7.1 & -15.4 & -1.1 & -9.0 \\
\hline G & -2.2 & -5.3 & -2.3 & -5.1 & -0.9 & -7.9 & -1.8 & -9.1 & & \\
\hline $\mathrm{H}$ & -2.1 & -3.9 & -2.1 & -4.3 & -1.1 & -8.1 & -2.1 & -7.2 & & \\
\hline I & -1.1 & -4.1 & -1.1 & -4.2 & -0.8 & -8.2 & -2.0 & -7.3 & & \\
\hline
\end{tabular}

${ }^{2}$ Phenological stages as defined by Felipe (1977) for almond and Baggiolini (1957) for the rest of species.

30 min and was then increased by $3{ }^{\circ} \mathrm{C} \cdot \mathrm{h}^{-1}$ to $7^{\circ} \mathrm{C}$. The range of FTs (Table 2) essayed for each phenological stage and species was decided after examination of previously published information (Ballard et al., 1987, 1994, 1997, 1999; Grasselly, 1982; Micke, 1996; Osaer et al., 1998; Perraudin, 1965; Proebsting and Mills, 1978; Saunier, 1960 and 1978) and some preliminary trials. The seven FT programmed for each cultivar and phenological stage were the maximum and minimum temperatures of the ranges shown on Table 2 plus five more, evenly distributed within each range. The rates of the drop and rise of temperatures chosen resemble field freeze conditions. The air temperature recorded by the five thermopar probes in the vicinity of the samples did not differ by $>10 \%$ between them. The samples were then placed in a dark chamber and maintained at $17^{\circ} \mathrm{C}$ for another 24 to $48 \mathrm{~h}$ before examination. The buds were then detached from the spurs, placed for dissection into a petri dish and observed for frost damages on a stereo microscope. Though the pistil is the most frost-tender organ in the flower before fertilization, and the endocarp after set (Ministerio de Agricultura, Pesca and Alimentación, 1998), other floral structures are also sometimes injured. For this reason, buds were considered frost damaged when any tissue in them was brownish. The proportion of frost damaged buds, expressed as a decimal, was then calculated. The frost temperature for the relationships was calculated as the mean of the records from the five thermopar probes for the $30 \mathrm{~min}$ at minimum temperature.

Statistical analysis. The relationships between frost temperature (dependent variable) and the proportion of frost damaged buds (independent variable) for each cultivar, year, and phenological stage were evaluated by fitting linear regression models with the Linear Regression Procedure of SPSS (SPSS Inc., Chicago, Ill.). The 95\% confidence intervals were also calculated for the coefficients of each regression line. These intervals contain the true population regression line $95 \%$ of the time, and enable us to see the region in which the entire regression line lies (Neter et al, 1996; Quinn and Keough, 2002).

Analysis of covariance was then performed with the GLMProcedure of SPSS (Marini, 1999; Miranda-Jiménez and Royo-Díaz, 2003) to test the equality of regressions for different years and cultivars of the same species. The year or cultivar, respectively, were included as the indicator or dummy variable and the proportion of flower buds damaged was included as the covariate. Because the indicator variable and the interaction terms containing them were not significant $(p>0.05)$ for any of the species, data from all the years and cultivars were pooled so that a single regression was finally calculated for each phenological stage and specie. The equality of regressions for different species at the same phenological stage was tested using the same methodology outlined above. When the species and the interaction term containing the species were significant $(p>0.05)$, a Duncan's multiple range test $(p>0.05)$ for parameters (independent term and slope) was applied to obtain the differences between species.Aspecies will be hardier when its independent term was lower or its slope steeper. When the Duncan's test showed no significant differences between species, data for similar species was pooled, so that a single regression was calculated for them. The final relationships were used to calculate the lethal temperatures, along with their respective $95 \%$ confidence intervals, for the $\mathrm{LT}_{10}$ and $\mathrm{LT}_{90}$ of each species or group of species. Confidence intervals for a particular point in the regression line were obtained from the values of the confidence band in that point.

\section{Results}

Temperature and damage relationships and sensibility order. The slopes, intercepts, and coefficients of determination (at each phenological stage and for each species) for the relationships between frost temperature (for half an hour), and the proportion (decimal) of bud/flower damage are shown on Table 3. The relationships and their coefficients were always significant, and their coefficients of determination were on most occasions above 0.5 . The analysis of covariance to test the equality of regressions for different species at the same phenological stage was always significant, so Duncan's test could be applied to obtain differences between species (Table 3 ).

At prebloom stages blackthorn, Japanese plum and peach had similar relationships with steeper slopes and usually also lower intercepts, so they were the hardiest species. Almond relationships had slopes similar to the latter species, but their intercepts were generally higher, so it was tenderer. Finally, sweet cherry was always the tenderest species, because the slopes of their relationships were less steep and, on most occasions, they also had higher intercepts.

At bloom, differences between species broadened. Blackthorn was the hardiest species, followed by Japanese plum and peach, which had slopes similar to the former, but higher intercepts. Sweet cherry was again at this stage the tenderest species. Almond had the least steep slope, but was not tenderer than sweet cherry due to a lower intercept.

At postbloom stages cherry was not studied. Blackthorn again proved to be the hardiest species and almond the tenderest. Japanese plum was generally as hardy as blackthorn, whereas peach was generally as tender as almond.

The data for the species with significantly similar hardiness at a certain phenological stage were pooled and new relationships (Table 4) were found with them.

Confidence intervals for the relationships. Confidence intervals for the final temperature/ damage relationships(Table 5) were fairly broad, in spite of the homogeneous material used and the great degree of control applied in the freeze treatments. The mean extent of the interval, for both slope and intercept, was about $\pm 30 \%$ respect from the mean value of the coefficients. Intervals for the tenderest species (almond and cherry) were even broader, especially at prebloom and bloom stages, in which they extended up to $\pm 80 \%$ to $90 \%$.

Lethal temperatures for the $10 \%$ and the 
90\% of the organs. When visible swelling started (Table 6), lethal temperatures (LT) began to rise rapidly, and the separation between mean $\mathrm{LT}_{10}$ and $\mathrm{LT}_{90}$ narrowed. The rise in temperature was lower in sweet cherry because their LT for early stages (B and C) were much higher than for the other species. The confidence interval's breadth was fairly high for all the LTs, since interval breadths for $\mathrm{LT}_{10}$ ranged from about $3{ }^{\circ} \mathrm{C}$ at prebloom stages to about $1{ }^{\circ} \mathrm{C}$ at postbloom. Intervals for $\mathrm{LT}_{90}$ ranged from about $6^{\circ} \mathrm{C}$ at prebloom stages to about $2{ }^{\circ} \mathrm{C}$ at postbloom. Except for the hardiest species at prebloom and bloom stages, the separation between confidence intervals for $\mathrm{LT}_{10}$ and $\mathrm{LT}_{90}$ was instead fairly narrow, given that the gap between them was
$<2{ }^{\circ} \mathrm{C}$ at prebloom stages, and generally $<1{ }^{\circ} \mathrm{C}$ from bloom onwards. The confidence intervals for LT in almond and cherry sometimes even overlapped.

\section{Discussion}

An important element in frost protection is deciding when to activate the system, and this decision must be based on the temperature at which injury is likely to occur. Critical temperatures for decidous fruit are widely published, but their origins and limitations are not usually well documented. Those indices have usually been obtained from careful field observations, and while they do provide very valuable in-

Table 3. Relationships between proportion of flower buds or fruit damaged (x, as decimal) and temperature $\left(\mathrm{y},{ }^{\circ} \mathrm{C}\right)$ in the species tested from the phenological stages (PEs) B to I.

\begin{tabular}{|c|c|c|c|c|}
\hline \multirow[b]{2}{*}{$\mathrm{PE}^{\mathrm{z}}$} & \multirow[b]{2}{*}{ Species } & \multicolumn{3}{|c|}{$\mathrm{y}=\mathrm{b}_{0}+\mathrm{b}_{1} \mathrm{x}$} \\
\hline & & $\mathrm{b}_{0}$ & $\mathrm{~b}_{1}$ & $R^{2}$ \\
\hline \multirow[t]{5}{*}{$\overline{\mathrm{B}}$} & Blackthorn & $-6.6^{* * * *}$ & $-10.1 \mathrm{a}^{* * *}$ & $0.885^{* * *}$ \\
\hline & Japanese plum & $-5.1^{* * * *}$ & $-12.4 \mathrm{a}^{* * * *}$ & $0.782^{* * *}$ \\
\hline & Peach & $-5.3^{* *}$ & $-9.7 \mathrm{a}^{* * *}$ & $0.564^{* * * *}$ \\
\hline & Almond & $-6.0^{* *}$ & $-9.1 \mathrm{a}^{* *}$ & $0.684^{* *}$ \\
\hline & Sweet cherry & $-6.2^{* * *}$ & $-2.2 b^{* * *}$ & $0.454^{* *}$ \\
\hline \multirow[t]{5}{*}{$\mathrm{C}$} & Blackthorn & $-6.6 \mathrm{a}^{\mathrm{y}^{* * * *}}$ & $-9.0 a^{* * *}$ & $0.877^{* * * *}$ \\
\hline & Japanese plum & $-7.2 \mathrm{a}^{* * *}$ & $-8.6 a^{* * *}$ & $0.675^{* * *}$ \\
\hline & Peach & $-4.7 a^{*}$ & $-6.5 a^{* *}$ & $0.664^{* *}$ \\
\hline & Almond & $-3.0 b^{*}$ & $-8.5 \mathrm{a}^{* * *}$ & $0.746^{* * *}$ \\
\hline & Sweet cherry & $-2.0 b^{* * *}$ & $-5.8 b^{* * * *}$ & $0.667^{* * *}$ \\
\hline \multirow[t]{5}{*}{ D } & Blackthorn & $-4.9 a^{* * *}$ & $-6.6 a^{* * *}$ & $0.451^{* * *}$ \\
\hline & Japanese plum & $-3.7 \mathrm{a}^{* * * *}$ & $-6.7 a^{* * *}$ & $0.606^{* * *}$ \\
\hline & Peach & $-3.6 a^{* * *}$ & $-7.3 \mathrm{a}^{* * *}$ & $0.868^{* * *}$ \\
\hline & Almond & $-2.2 b^{*}$ & $-8.9 \mathrm{a}^{* * *}$ & $0.880^{* * *}$ \\
\hline & Sweet cherry & $-1.6 b^{*}$ & $-3.6 b^{* *}$ & $0.382^{* *}$ \\
\hline \multirow[t]{5}{*}{$\mathrm{F}$} & Blackthorn & $-3.6 a^{* * *}$ & $-5.5 \mathrm{ab}^{* * * *}$ & $0.734^{* * *}$ \\
\hline & Japanese plum & $-1.5 b^{* * *}$ & $-5.3 a b^{* * * *}$ & $0.632^{* * * *}$ \\
\hline & Peach & $-1.8 b^{*}$ & $-7.3 \mathrm{a}^{* * *}$ & $0.802^{* * *}$ \\
\hline & Almond & $-2.5 a b^{* *}$ & $-2.6 c^{*}$ & $0.490^{*}$ \\
\hline & Sweet cherry & $-0.8 \mathrm{c}^{*}$ & $-4.0 b^{* * * *}$ & $0.701^{* * * *}$ \\
\hline \multirow[t]{4}{*}{ G } & Blackthorn & $-2.9 \mathrm{a}^{* * *}$ & $-3.9 \mathrm{a}^{* * *}$ & $0.781^{* * *}$ \\
\hline & Japanese plum & $-1.5 b^{* * *}$ & $-4.2 \mathrm{a}^{* * *}$ & $0.764^{* * * *}$ \\
\hline & Peach & $-2.4 a^{* * *}$ & $-1.6 b^{* * * *}$ & $0.613^{* * * *}$ \\
\hline & Almond & $-2.4 \mathrm{a}^{* * *}$ & $-1.8 b^{* * * *}$ & $0.581^{* * *}$ \\
\hline \multirow[t]{4}{*}{$\mathrm{H}$} & Blackthorn & $-2.0 * *$ & $-3.3 \mathrm{a}^{* * *}$ & $0.508^{* * *}$ \\
\hline & Japanese plum & $-1.7^{* * * *}$ & $-4.0 a^{* * *}$ & $0.742^{* * *}$ \\
\hline & Peach & $-2.0^{* * * *}$ & $-1.5 b^{*}$ & $0.807^{* * *}$ \\
\hline & Almond & $-2.4^{* * * *}$ & $-1.4 b^{* *}$ & $0.693^{* *}$ \\
\hline \multirow[t]{4}{*}{ I } & Blackthorn & $-2.1 \mathrm{a}^{* * *}$ & $-3.5 \mathrm{a}^{* * *}$ & $0.573^{* * * *}$ \\
\hline & Japanese plum & $-1.6 a^{* * *}$ & $-3.7 a^{* * *}$ & $0.440^{* * *}$ \\
\hline & Peach & $-1.4 b^{* * *}$ & $-2.4 a^{* * *}$ & $0.793^{* * *}$ \\
\hline & Almond & $-2.3 \mathrm{a}^{* * * *}$ & $-0.7 b^{* * *}$ & $0.539^{* * *}$ \\
\hline
\end{tabular}

2Phenological stages as defined by Felipe (1977) for almond and Baggliolini (1956) for the rest of species. ${ }^{y}$ Coefficients in columns for each phenological stage followed by different letters are significantly different at $P<0.05$ (Duncan's multiple range test).

${ }^{*, * * * * * *}$ Equation coefficients or regression that are significant at $P<0.05,0.01$, or 0.001 , respectively.

Table 4. Relationships between proportion of flower buds or fruit damaged $(\mathrm{x}$, decimal $)$ and temperature $\left(\mathrm{y},{ }^{\circ} \mathrm{C}\right)$ for the species with similar regression coefficients on each phenological stage (PE) (see Table 3).

\begin{tabular}{llccc}
\hline & & \multicolumn{3}{c}{$\mathrm{y}=\mathrm{b}_{0}+\mathrm{b}_{1} \mathrm{x}$} \\
\cline { 3 - 5 } $\mathrm{PE}^{\mathrm{z}}$ & Species $^{\mathrm{y}}$ & $\mathrm{b}_{0}$ & $\mathrm{~b}_{1}$ & $R^{2}$ \\
\hline $\mathrm{B}$ & $\mathrm{Al}, \mathrm{Bl}, \mathrm{Pe}, \mathrm{Pl}$ & $-5.5^{* * * *}$ & $-11.0^{* * * *}$ & $0.737^{* * *}$ \\
$\mathrm{C}$ & $\mathrm{B}, \mathrm{Pe}, \mathrm{Pl}$ & $-7.3^{* * *}$ & $-7.2^{* * *}$ & $0.583^{* * * *}$ \\
$\mathrm{D}$ & $\mathrm{B}, \mathrm{Pe}, \mathrm{Pl}$ & $-4.0^{* * *}$ & $-6.5^{* * *}$ & $0.596^{* * *}$ \\
$\mathrm{~F}$ & $\mathrm{Pe}, \mathrm{Pl}$ & $-1.5^{* * *}$ & $-5.7^{* * *}$ & $0.612^{* * *}$ \\
$\mathrm{G}$ & $\mathrm{Al}, \mathrm{Pe}$ & $-2.4^{* * *}$ & $-1.7^{* * *}$ & $0.610^{* * * *}$ \\
$\mathrm{H}$ & $\mathrm{Bl}, \mathrm{Pl}$ & $-1.7^{* * *}$ & $-3.8^{* * *}$ & $0.703^{* * *}$ \\
$\mathrm{H}$ & $\mathrm{Al}, \mathrm{Pe}$ & $-2.2^{* * *}$ & $-1.6^{* * * *}$ & $0.710^{* * *}$ \\
$\mathrm{I}$ & $\mathrm{B} 1, \mathrm{Pl}$ & $-1.7^{* * *}$ & $-3.7^{* * *}$ & $0.492^{* * *}$ \\
\hline
\end{tabular}

${ }^{2}$ Phenological stages as defined by Felipe (1977) for almond and Baggliolini (1957) for the rest of species.

${ }^{y} \mathrm{Al}=$ almond, $\mathrm{Bl}=$ blackthorn, $\mathrm{Ch}=$ sweet cherry, $\mathrm{Pe}=$ peach, $\mathrm{Pl}=$ japanese plum.

${ }^{* * * * * * * *}$ Equation coefficients or regression that are significant at $P<0.05,0.01$, or 0.001 , respectively. formation, the lack of a standardized method has lead to the coexistence of many different indices for each species. As a consequence, it is very difficult (or simply impossible) to compare them and deduce the influence of the specie over bud frost hardiness. In addintion, some of the most cultivated Prunus species lacked complete indices. In this study frosts were made with a common methodology for all species, and buds (or flowers) were sampled with the utmost care so that their phenological stage and condition were uniform within the samples. The relationships obtained here were always significant, and their coefficients of determination were generally quite high. However, confidence intervals were quite broad, reflecting high variability. An explanation for these results are the many factors still unknown or difficult to control which influence bud or flower hardiness. So, frost resistance varies within the tree itself in the same extent that varies within orchards, cultivars and species (Proebsting and Mills, 1978; Saunier, 1960). Flower bud development is a continuous process associated with a progressive vulnerability of the pistil to low temperatures (Proebsting and Mills, 1961), and pistil development is not strictly linked with changes in the external flower appearance. For this reason, even apparently similar flowers in the same phenological stage and in a similar position on the tree often present differences in cold resistance. This also takes place in laboratory tests under controlled conditions, and appears to indicate an internal attribute that would make some flowers hardier than others (Wisniewski et al., 1997).

Although the variability of data shows that critical temperatures for species are not biological constants, it has been possible to establish significant differences in hardiness between species. As a whole, greater hardiness was translated particularly into steeper slopes, so that the difference between hardy and tender species was due to the latter having less distance between the temperature at which some injury occurs $\left(\mathrm{LT}_{10}\right)$ and the one at which few buds survive $\left(\mathrm{LT}_{90}\right)$. Cherry has proven the tenderest species, even in early developmental stages such as B and C. Sweet cherry has usually been considered hardier than peach through dormancy till the B stage, and more tender from that stage onwards (Osaer et al., 1998; Proebsting and Mills, 1972; Saunier, 1960). Though it was not confirmed at the time of publication, field observations conducted by Osaer et al. (1998) contained strong indications that critical temperatures for sweet cherry at $\mathrm{B}$ and ' $\mathrm{C}$ ' stages were about $-3{ }^{\circ} \mathrm{C}$, a temperature much higher than the -4.5 or $-5^{\circ} \mathrm{C}$ previously stated. The results in the present work seem to confirm the preliminary observations of Osaer et al. (1998). So, this species could be considered much more frost tender than peach or plum at these early stages.

Almond has been the second species in the frost tenderness rank, surpassed only by sweet cherry. Furthermore, at postbloom stages, the difference between the $\mathrm{LT}_{10}$ and $\mathrm{LT}_{90}$ is $<1.5$ ${ }^{\circ} \mathrm{C}$ (and dropped to only $0.6^{\circ} \mathrm{C}$ in the I stage), much lower than for the other studied Prunus species. The authors are unaware of previous studies that detail this behavior in almond. 
At prebloom stages, japanese plums appear to be less hardy than the european plums cited in the literature (Osaer et al.; 1998, Perraudin, 1965, Proebsting and Mills, 1978), as the critical temperatures cited are out of the ranges defined by the confidence intervals obtained in this study. From the bloom stage onwards, the lethal temperatures cited for European plums are very close to those found for Japanese plum in this study. Peach has demonstrated a hardiness similar to the japanese plum at prebloom and bloom stages, and is less hardy at postbloom. Blackthorn, for which no previous information existed, has consistently proven itself to be the hardiest species from bud swell to jacket split. In short, between the B to I stages, the spring frost hardiness order of the species, from the least to most hardy, is as follows: sweet cherry, almond, peach, Japanese plum, and blackthorn.

Upper and lower limit values in the confidence interval for a certain degree of injury are equivalent to the higher and lower temperatures, respectively, at which $95 \%$ of the samples are expected to be injured in that extent. As expected, the gap between $\mathrm{LT}_{10}$ and $\mathrm{LT}_{90}$ narrowed as the phenological stage advanced (Proebsting and Mills, 1978), and consequently the gap reduction was even higher for their confidence intervals. Those temperature differences are much lower than the ones previously cited in the available

Table 5. 95\% Upper (UL) and lower (LL) limits in the confidence intervals for the intercept $\left(\mathrm{b}_{0}\right)$ and the slope $\left(b_{1}\right)$ in the relationships between proportion of flower buds or fruit damaged and temperature shown in Tables 3 and 4.

\begin{tabular}{|c|c|c|c|c|c|}
\hline \multirow[b]{3}{*}{$\mathrm{PE}^{z}$} & \multirow[b]{3}{*}{ Species $^{y}$} & \multicolumn{4}{|c|}{ Confidence intervals for $\mathrm{b}_{0}$ and $\mathrm{b}_{1}$} \\
\hline & & \multicolumn{2}{|c|}{$\mathrm{b}_{0}$} & \multicolumn{2}{|c|}{$\mathrm{b}_{1}$} \\
\hline & & $\overline{\mathrm{LL}}$ & $\overline{\mathrm{UL}}$ & LL & UL \\
\hline \multirow[t]{2}{*}{$\overline{\mathrm{B}}$} & $\mathrm{Al}, \mathrm{Bl}, \mathrm{Pe}, \mathrm{Pl}$ & -6.3 & -4.7 & -12.5 & -9.5 \\
\hline & $\mathrm{Ch}$ & -7.2 & -5.1 & -3.7 & -0.7 \\
\hline \multirow[t]{3}{*}{$\mathrm{C}$} & $\mathrm{Bl}, \mathrm{Pe}, \mathrm{Pl}$ & -7.9 & -6.6 & -8.4 & -6.0 \\
\hline & $\mathrm{Al}$ & -5.3 & -0.8 & -11.6 & -5.4 \\
\hline & $\mathrm{Ch}$ & -3.0 & -1.1 & -7.2 & -4.3 \\
\hline \multirow[t]{3}{*}{$\mathrm{D}$} & $\mathrm{Bl}, \mathrm{Pe}, \mathrm{Pl}$ & -4.6 & -3.5 & -7.4 & -5.6 \\
\hline & $\mathrm{Al}$ & -3.8 & -0.7 & -11.1 & -6.7 \\
\hline & $\mathrm{Ch}$ & -3.1 & -0.2 & -6.0 & -1.1 \\
\hline \multirow[t]{4}{*}{$\mathrm{F}$} & $\mathrm{Bl}$ & -4.2 & -3.0 & -6.7 & -4.3 \\
\hline & $\mathrm{Pe}, \mathrm{Pl}$ & -2.0 & -0.9 & -6.7 & -4.8 \\
\hline & $\mathrm{Al}$ & -3.8 & -1.1 & -4.7 & -0.6 \\
\hline & $\mathrm{Ch}$ & -1.5 & 0.0 & -5.5 & -2.6 \\
\hline \multirow[t]{3}{*}{ G } & $\mathrm{B} 1$ & -3.5 & -2.2 & -4.7 & -3.0 \\
\hline & $\mathrm{Pl}$ & -2.0 & -1.0 & -5.0 & -3.4 \\
\hline & $\mathrm{Al}, \mathrm{Pe}$ & -2.6 & -2.1 & -2.2 & -1.3 \\
\hline \multirow[t]{2}{*}{$\mathrm{H}$} & $\mathrm{Bl}, \mathrm{Pl}$ & -2.1 & -1.4 & -4.3 & -3.2 \\
\hline & $\mathrm{Al}, \mathrm{Pe}$ & -2.5 & -1.8 & -2.2 & -1.0 \\
\hline \multirow[t]{3}{*}{ I } & $\mathrm{Bl}, \mathrm{Pl}$ & -2.1 & -1.2 & -4.5 & -3.0 \\
\hline & $\mathrm{Pe}$ & -1.8 & -1.1 & -3.0 & -1.8 \\
\hline & $\mathrm{Al}$ & -2.4 & -2.2 & -1.0 & -0.5 \\
\hline
\end{tabular}

${ }^{\mathrm{z}}$ Phenological stages as defined by Felipe (1977) for almond and Baggliolini (1957) for the rest of species.

${ }^{\mathrm{y}} \mathrm{Al}=$ almond, $\mathrm{Bl}=$ blackthorn, $\mathrm{Ch}=$ sweet cherry, $\mathrm{Pe}=$ peach, $\mathrm{Pl}=$ japanese plum.

literature (Proebsting and Mills, 1978; Stewart et al., 1984). Therefore, the difference between slight and severe bud frost injury has proven to be only a few tenths of degree for the tenderest species. At some stages in almond and sweet cherry slight and severe bud injury are equally possible at the same temperature.

In the field it is difficult to determine temperature variations of $<1^{\circ} \mathrm{C}$ given that variations in the temperature registered at different points within the orchard, or even in the same tree, can be greater (Osaer et al., 1998). Even when frost and bud characteristics are highly homogeneous, as is the case in this study, the temperature range for a given degree of injury has been quite broad. Due to the many factors influencing the response of a bud to low temperatures, and because the characteristics of spring frost (duration, minimum temperature, and the rate at temperature increases or decreases) are highly variable, it is very difficult to accurately predict the degree of injury that may occur following a spring frost by using temperatures alone. Consequently, when critical temperatures are used in making decisions as to when to begin active frost protection, a prudent measure would be to take the temperature references from the upper limits in the confidence intervals found in this work, instead of using the mean lethal temperatures.

\section{Literature Cited}

Baggiolini, M. 1952. Les stades repérés des arbres fruitiers à noyau. Rev. Romande Agr. Viticult. Arboricult. 8:1-8.

Ballard, J. K., E.L. Proebsting, and R.B. Tukey. 1987. Prunes: Critical temperatures for blossom buds. Wash. State Univ. Ext. Cir. 1186.

Ballard, J. K., E.L. Proebsting, and R.B. Tukey. 1994. Apricots: Critical temperatures for blossom buds. Wash. State Univ. Ext. Cir. 1240.

Ballard, J. K., E.L. Proebsting, and R.B. Tukey. 1997. Cherries: Critical temperatures for blossom buds. Wash. State Univ. Ext. Cir. 1128.

Table 6. Mean lethal temperatures for the $10 \%\left(\mathrm{LT}_{10}\right)$ and the $90 \%\left(\mathrm{LT}_{90}\right)$, of the flower buds or fruit for each of the phenological stages (PE) and species tested. 95\% confidence intervals are also given. Mean and confidence interval values were obtained from the relationships shown in Tables 3,4 , and 5 .

\begin{tabular}{|c|c|c|c|c|c|c|c|}
\hline $\mathrm{PE}^{\mathrm{z}}$ & Species & $\mathrm{LT}_{1}$ & $\mathrm{LT}_{\mathrm{O}}$ & \multicolumn{2}{|c|}{$\begin{array}{l}\text { Confidence interval } \\
\text { for } \mathrm{LT}_{10}\end{array}$} & \multicolumn{2}{|c|}{$\begin{array}{l}\text { Confidence interval } \\
\text { for } \mathrm{LT}_{90}\end{array}$} \\
\hline$\overline{\mathrm{B}}$ & $\mathrm{Al}, \mathrm{Bl}, \mathrm{Pe}, \mathrm{Pl}^{\mathrm{x}}$ & -6.6 & -15.4 & -5.6 & -7.6 & -13.2 & -17.6 \\
\hline \multirow[t]{3}{*}{$\mathrm{C}$} & $\mathrm{Bl}, \mathrm{Pe}, \mathrm{Pl}$ & -8.0 & -13.8 & -7.2 & -8.7 & -12.0 & -15.5 \\
\hline & $\mathrm{Al}$ & -3.9 & -10.7 & -1.4 & -6.4 & -5.7 & -15.7 \\
\hline & $\mathrm{Ch}$ & -2.6 & -7.2 & -1.5 & -3.8 & -5.0 & -9.5 \\
\hline D & $\mathrm{Bl}, \mathrm{Pe}, \mathrm{Pl}$ & -4.7 & -9.9 & -4.0 & -5.3 & -8.5 & -11.3 \\
\hline \multirow[t]{4}{*}{$\mathrm{F}$} & $\mathrm{B} 1$ & -4.2 & -8.6 & -3.5 & -4.9 & -6.9 & -10.3 \\
\hline & $\mathrm{Pe}, \mathrm{Pl}$ & -2.0 & -6.6 & -1.4 & -2.7 & -5.2 & -8.1 \\
\hline & $\mathrm{Al}$ & -2.7 & -4.8 & -1.2 & -4.2 & -1.7 & -8.0 \\
\hline & $\mathrm{Ch}$ & -1.2 & -4.4 & -0.3 & -2.0 & -2.3 & -6.4 \\
\hline \multirow[t]{3}{*}{ G } & $\mathrm{Bl}$ & -3.3 & -6.3 & -2.5 & -4.0 & -4.9 & -7.8 \\
\hline & $\mathrm{Pl}$ & -1.9 & -5.3 & -1.4 & -2.5 & -4.1 & -6.5 \\
\hline & $\mathrm{Al}, \mathrm{Pe}$ & -2.6 & -4.0 & -2.3 & -2.9 & -3.3 & -4.6 \\
\hline I & $\mathrm{Al}$ & -2.4 & -3.0 & -2.2 & -2.5 & -2.6 & -3.3 \\
\hline
\end{tabular}

${ }^{2}$ Phenological stages as defined by Felipe (1977) for almond and Baggliolini (1957) for the rest of species.

${ }^{y} \mathrm{UL}=$ upper limit, $\mathrm{LL}=$ lower limit.

${ }^{\mathrm{x}} \mathrm{A}=$ almond, $\mathrm{Bl}=$ blackthorn, $\mathrm{Pe}=$ peach, $\mathrm{Pl}=$ japanese plum 
Ballard, J. K., E.L. Proebsting, and R.B. Tukey. 1999. Peaches: Critical temperatures for blossom buds. Wash. State Univ. Ext. Cir. 914.

Ercisli, S. 2003. Relationship of seasonal changes in carbohydrates and cold hardiness in buds of two rose hip genotypes. Euro. J. Hort. Sci. 68:63-66.

Faust, M. 1989. Physiology of temperate zone fruit trees. Wiley-Interscience, N.Y.

Felipe, A. 1977. Almendro: estados fenológicos. Inform. Técn. Econ. Agr. 27:60-61.

Grasselly, C. 1982. L'Amandier. Centre technique interprofessionnel des fruit et legumes, Paris, France.

Marini, R.P. 1999. Estimating apple diameter from fruit mass measurements to time thinning sprays. HortTechnology 9:109-113.

Micke, W.C.(ed.). 1996. Almond production manual. Univ. Calif. Div. Agr. Natural Resour. Agr. Sci. Publ. 3364.

Ministerio de Agricultura, Pesca y Alimentación. 1998. Síntomas específicos provocados por las heladas primaverales en frutales de pepita y hueso y de los órganos fructíferos. Ministerio de Agricultura, Pescay Alimentación. EntidadEstatal de Seguros Agrarios. Madrid, Spain.

Miranda-Jiménez, C. and Royo-Díaz, J.B. 2003.
A statistical model to estimate potential yields in peach before bloom. J. Amer. Soc. Hort. Sci 128:297-301.

Neter, J., M.H. Kutner, C.J. Nachtshein, and W. Wasserman. 1996. Applied linear regression models. 3rd ed. Irwin, Homewood Ill.

Osaer, A., P. Vaysse, J.F. Berthoumieu, A. Audubert, and M. Trillot. 1998. Gel de printemps. Protection des vergers. Centre technique interprofessionnel des fruit et legumes, Paris, France.

Perraudin, G. 1965. Résistance au gel printanier de quelques espèces et variétés fruitières. Agr. Romande 4:70-73.

Pfammatter, W. and M. Evequoz. 1975. La résistance aux gelées de différentes cultures. Rev. Suiss. Viticult. Arboricult. Hort. 7:19-23.

Proebsting, E.L. and H.H. Mills. 1961. Loss of hardiness by peach fruit buds as related to their morphological development during the pre-bloom and bloom period. Proc. Am. Soc. Hort. Sci. 78:104-110.

Proebsting, E.L. and H.H. Mills. 1972. A comparison of hardiness responses in fruit buds of 'Bing' cherry and 'Elberta' peach. J. Amer. Soc. Hort. Sci. 97:802-806.

Proebsting, E.L. and H.H. Mills. 1978. Low temperature resistance of developing flower buds of six decidous fruit species. J. Amer. Soc. Hort. Sci. 103:192-198.

Quinn, G.P. and M.J. Keough. 2002. Experimental design and data analysis for biologists. Cambridge Univ. Press, Cambridge, U.K.

Rodrigo, J. 2000. Spring frost in decidous fruit trees. Morphological damage and flower hardiness. Scientia Hort. 85:155-173.

Saunier, R. 1960. La lutte contre les gelées printanières chez les arbres fruitiers. I. Pomologie Française 2:5-12.

Saunier, R. 1978. Sensibilité variétale aux gels chez les cerisiers, pruniers, pêchers et nectariniers, $\mathrm{p}$. 69-84. In INVUFLEC, Ed. Lutte contre les gelées. J. Natl. d'info., Angers, France.

Stewart, T.R., R.W. Katz, and A.H. Murphy. 1984. Value of weather information:A descriptive study of the fruit frost problem. Bul. Amer. Meteorol. Soc. 65:126-137.

Westwood, M.N. 1993. Temperate-zone pomology: physiology and culture. Timber Press, Portland, Ore

Wisniewski, M., S.E. Lindow, and E.N. Ashworth. 1997. Observations of ice nucleation and propagation in plants using infrared video thermography. Plant Physiol. 113:327-334. 